\title{
BOTTOM-UP FACTORS INFLUENCING RIPARIAN WILLOW RECOVERY IN YELLOWSTONE NATIONAL PARK
}

\author{
Michael T. Tercek ${ }^{1}$, Robert Stottlemyer ${ }^{2}$, and Roy Renkin ${ }^{3}$
}

\begin{abstract}
After the elimination of wolves (Canis lupis L.) in the 1920s, woody riparian plant communities on the northern range of Yellowstone National Park (YNP) declined an estimated 50\%. After the reintroduction of wolves in 1995-1996, riparian willows (Salix spp.) on YNP’s northern range showed significant growth for the first time since the 1920s. However, the pace of willow recovery has not been uniform. Some communities have exceeded $400 \mathrm{~cm}$, while others are still at pre-1995 levels of $<80 \mathrm{~cm}$ mean height. We took intensive, repeated measurements of abiotic factors, including soil and water-table characteristics, to determine whether these factors might be contributing to the varying pace of willow recovery. Willows at all of our study sites were "short" ( $<250 \mathrm{~cm}$ max. height) prior to 1995 and have recovered to varying degrees since. We contrasted "tall" (>250 cm max. height) willow sites where willows had escaped elk (Cervus elaphus L.) browsing with "short" willow sites that could still be browsed. Unlike studies that manipulated willow height with fences and artificial dams, we examined sites that had natural growth differences in height since the reintroduction of wolves. Tall willow sites had greater water availability, more-rapid net soil nitrogen mineralization, greater snow depth, lower soil respiration rates, and cooler summer soil temperatures than nearby short willow sites. Most of these differences were measured both in herbaceous areas adjacent to the willow patches and in the willow patches themselves, suggesting that they were not effects of varying willow height recovery but were instead preexisting site differences that may have contributed to increased plant productivity. Our results agree with earlier studies in experimental plots which suggest that the varying pace of willow recovery has been influenced by abiotic limiting factors that interact with top-down reductions in willow browsing by elk.
\end{abstract}

Key words: Yellowstone National Park, Salix, willow, wolf reintroduction, trophic cascade, abiotic factors, bottom-up factors, riparian vegetation.

After the elimination of wolves (Canis lupus L.) in the $1920 \mathrm{~s}$, riparian willow (Salix spp.), aspen (Populus tremuloides Michx.), and cottonwoods (Populus balsamifera L., Populus angustifolia James, and their hybrids) declined an estimated $50 \%$ on the northern range of Yellowstone National Park, which is the 153,000-ha area occupied by the park's northern elk herd in the winter (Chadde and Kay 1991). In subsequent decades, several researchers concluded that the removal of wolves triggered the riparian plant decline by allowing for the growth of an unprecedentedly large elk (Cervus elaphus L.) herd that was overbrowsing the range (reviewed in Wagner 2006). After the reintroduction of wolves in 1995-1996, riparian willows on Yellowstone's northern range have shown significant growth and recruitment for the first time since the 1920s (Ripple and Beschta 2004a, 2004b, Beyer et al. 2007). Willow stands that had averaged $<80 \mathrm{~cm}$ in height prior to 1995 in some cases grew to greater than $400 \mathrm{~cm}$
(Tercek unpublished data). The prevailing explanation for this riparian plant recovery describes a "top-down trophic cascade" in which elk browsing increased when wolves were absent and decreased again following wolf reintroduction in 1995-1996 (Ripple et al. 2001, Beschta 2003, 2005, Larsen and Ripple 2003, Ripple and Beschta 2004a).

Height recovery of riparian plants, particularly willows, has not been uniform across the northern range since 1995, and there are 2 competing explanations for this uneven recovery. The first explanation involves wolf-mediated changes in elk behavior. The second explanation ascribes more importance to abiotic factors, such as water availability, that limit plant productivity to varying degrees at different sites.

The behaviorally mediated, top-down theory (first explanation) explains the patchy distribution of tall and short willow as the result of elk avoiding predation by wolves, and proponents of this theory have explicitly denied

\footnotetext{
${ }^{1}$ Walking Shadow Ecology, Box 1085, Gardiner, MT 59030. E-mail: tercek@yellowstoneecology.com

${ }^{2}$ U.S. Geological Survey, Fort Collins, CO 80526.

${ }^{3}$ Yellowstone Center for Resources, National Park Service, Yellowstone National Park, WY 82190.
} 
the importance of abiotic factors that might influence willow growth. Ripple and Beschta (2006), for example, state that "increased willow height is not related to patterns of moisture availability" and that willows are often taller in valley bottoms and shorter in the adjacent uplands because "the use of higher ground by elk is a risk-sensitive foraging strategy to avoid wolf encounters, detect wolves, and/or evade wolves." Additional studies also advocate the view that riparian plants (including willows, aspens, and cottonwoods) are shorter in upland habitats exclusively because these habitats have lower perceived predation risk for elk (e.g., Ripple and Beschta 2003, 2004a, 2004b, 2007). According to this theory, open areas and upland habitats have lower perceived predation risk because they contain fewer escape impediments and allow the elk to more easily see approaching wolves.

Recently, some aspects of the behaviorally mediated trophic-cascade theory have been called into question. First, Kauffman et al. (2007) found that the home ranges of Yellowstone's wolf packs do not overlap some of the riskiest areas for elk-a finding that complicates comparisons of vegetation inside versus outside high-density wolf areas (see Ripple et al. 2001). Second, elk actually perceive more rather than less predation risk in open areas (Creel et al. 2005, Creel and Winnie 2005, Fortin et al. 2005), and wolf predation occurs more often in open areas than in densely vegetated areas (Kauffman et al. 2007). Third, elk increase rather than decrease their consumption of willow when wolves are nearby (Creel and Christianson 2009). Finally, increased snow depth and density, which impede elk access to preferred herbacaeous forage, have been more strongly linked to the proportion of browsed woody stems (including willow) in elk diets than wolf presence or absence (Christianson and Creel 2008, Creel and Christianson 2009). Taken together, these results suggest that abiotic factors such as snow have a stronger influence on elk browsing behavior than wolves. If wolves are indeed having cascading effects on vegetation, these effects may be opposite from those previously suspected, and the presence of wolves may be increasing willow consumption rather than reducing it.

The second explanation for the nonuniform pace of willow recovery focuses on abiotic limiting factors that influence plant productivity, rather than on factors that affect elk behavior.
In a factorial experiment with fenced exclosures that eliminated elk browsing and artificial beaver dams that raised the subsurface water table, Bilyeu et al. (2008) found that willows inside the fenced exclosures "remained remarkably short" and that artificially raising the water table with dams produced greater and more temporally consistent (from year to year) willow height increases than fencing. In a related study, Johnston et al. (2007) demonstrated that ambient elk browsing actually increased the growth of willows relative to unbrowsed (fenced) willows because it improved aspects of plant architecture that facilitate transpiration and photosynthesis. They concluded that in the absence of artificial dams, "removing browsing [with exclosures] suppressed above ground [willow] productivity." If the view of Johnston et al. (2007) and Bilyeu et al. (2008) is correct, then the taller height of willows in low-lying areas may be due, at least in part, to these willows being closer to the subsurface water table than willows growing on more upland habitats.

Rather than using experimental fences and dams to manipulate willow height (Johnston et al. 2007, Bilyeu et al. 2008), the present study sought to determine possible abiotic differences between naturally occurring (nonexperimental) "tall" and "short" (defined below) willow sites. The abiotic factors of interest were water-table depth, soil moisture, soil respiration rate, net soil nitrogen mineralization (an index of nutrient availability), snow depth, and soil temperature.

We hypothesized that taller willow sites would have abiotic conditions more favorable to primary productivity than shorter willow sites. Such differences would support the view that abiotic factors interact with top-down mechanisms (Johnston et al. 2007, Bilyeu et al. 2008) and that both top-down and bottom-up factors have contributed to willow height recovery in Yellowstone. Alternatively, no significant differences between tall and short willow sites would support the view of Ripple and Beschta (2006), which explicitly denies the influence of abiotic factors on the varying pace of willow recovery in different parts of Yellowstone's northern range.

We conducted our field work in or near sites used by Bilyeu et al. (2008), Johnston et al. (2007), and Ripple and Beschta $(2006,2007)$. Our design contrasted willow communities of $<250 \mathrm{~cm}$ maximum height, which are still subject to browsing by elk, with nearby willow communities that had experienced greater 
TABLE 1. Descriptive statistics for site productivity and litter decomposition in intensively studied willow sites on the northern range of Yellowstone National Park. Height measurements were recorded in September, at the end of the growing season (prior to winter browsing), and therefore represent annual maxima. Standard deviations are in parentheses, and asterisks $(*)$ indicate means that differ significantly $(P<0.05)$.

\begin{tabular}{lcccccc}
\hline & & & & & & \multicolumn{2}{c}{$\begin{array}{c}\text { Mean percent } \\
\text { leaf litter } \\
\text { Sean patch } \\
\text { height }(\mathrm{cm})\end{array}$} & $\begin{array}{c}\text { Max. patch } \\
\text { height }(\mathrm{cm})\end{array}$ & $\begin{array}{c}\text { Min. patch } \\
\text { height }(\mathrm{cm})\end{array}$ & $\begin{array}{c}\text { Mean leaf } \\
\text { area covered } \\
\text { by willow }\end{array}$ & $\begin{array}{c}\text { litter production } \\
\left(\mathrm{kg} \cdot \mathrm{ha}^{-1}\right)\end{array}$ & $\begin{array}{c}\text { decomposition } \\
\text { after } 6 \text { months }\end{array}$ \\
\hline Short willow sites & $170^{*}(40)$ & 250 & 90 & $34 \% *(23)$ & $293 *(122)$ & $37 \%(10)$ \\
Tall willow sites & $313^{*}(78)$ & 460 & 140 & $65 \% *(17)$ & $1328^{*}(787)$ & $37 \%(10)$ \\
\hline
\end{tabular}

height recovery since 1995 and exceeded the $250 \mathrm{~cm}$ height that is thought to prevent elk browsing (Keigley and Frisina 1998). All of our sites were $<250 \mathrm{~cm}$ maximum height prior to 1995 (Singer et al. 1994, Singer unpublished data) and have since experienced varying levels of growth.

This study differs from both the experimental, exclosure-based and the top-down studies just described (Ripple and Beschta 2006, Johnston et al. 2007, Bilyeu et al. 2008) because it included intensive, repeated measurements throughout the entire year, rather than just during the peak of the growing season. This approach allowed us to determine whether sites differed with respect to snow depth, which may affect the intensity of winter elk browsing, and the intensity of early spring runoff events, which may affect willow growth rates (National Research Council 2002).

\section{Methods}

\section{Study Area}

Yellowstone's northern range is defined as the 153,000-ha area that serves as wintering grounds for the park's northern elk herd. After the wildfires and harsh winter of 1988, the size of the northern-range elk herd increased, and a new elk migration pattern more than doubled the range that lies outside of Yellowstone Park (Lemke et al. 1998). Because only two-thirds of the northern range is within the borders of Yellowstone, elk and other ungulates are exposed to hunting pressure in the adjacent national forest. The size of the elk herd has fluctuated greatly in the last 100 years, reaching a minimum of about 5000 animals in 1968, peaking at nearly 25,000 animals in the early 1990 s, and declining to $<10,000$ animals in recent years (Eberhardt et al. 2007).

Elevation ranges from approximately 1700 to $3600 \mathrm{~m}$, but most of the area is mid-elevation
(1950-2900 m) and dry (28-50 cm annual precipitation; National Research Council 2002). The steppe communities contain primarily big sagebrush (Artemisia tridentata Nutt.) and grasses such as Idaho fescue (Festuca idahoensis Elmer), with willows, aspen, and cottonwood comprising the bulk of woody riparian vegetation (Despain 1990, National Research Council 2002).

\section{Site Selection and Study Design}

Our study (June 2005-2007) focused on 6 northern-range willow communities. Three of these were "short" willow sites, with heights less than the $250 \mathrm{~cm}$ needed to escape elk browsing (Keigley and Frisina 1998); and 3 were "tall" willows sites, which had recovered to more than $250 \mathrm{~cm}$ since 1995. All of our sites were $<80 \mathrm{~cm}$ mean height prior to 1995 (Singer et al. 1994, Singer unpublished data) and have experienced varying rates of recovery since. The tall sites were selected so that they not only were more productive (measured as leaf litter production per square meter) but also contained a greater proportion of surface area covered by willow thickets (Table 1). Study sites were purposely located in or near sites used by previous researchers so that comparisons could be made to past work. Our short willow sites on Blacktail Deer Plateau were directly adjacent to fenced exclosure sites used by Bilyeu et al. (2008) and Johnston et al. (2007). Our Soda Butte Creek site was within the area studied by Ripple and Beschta (2006), and our Crystal Creek site was near ( $100 \mathrm{~m}$ from) the site used by Ripple and Beschta (2005). All the study sites contained only the willow species Salix bebbiana Sarg., Salix boothii Dorn, and Salix geyeriana Anderss., with only a very small number of Salix drummondiana Barratt ex. Hook. on the periphery.

Each study site contained 2 subplots: willow-shaded subplots and herbaceous subplots. Herbaceous subplots were adjacent to willow 


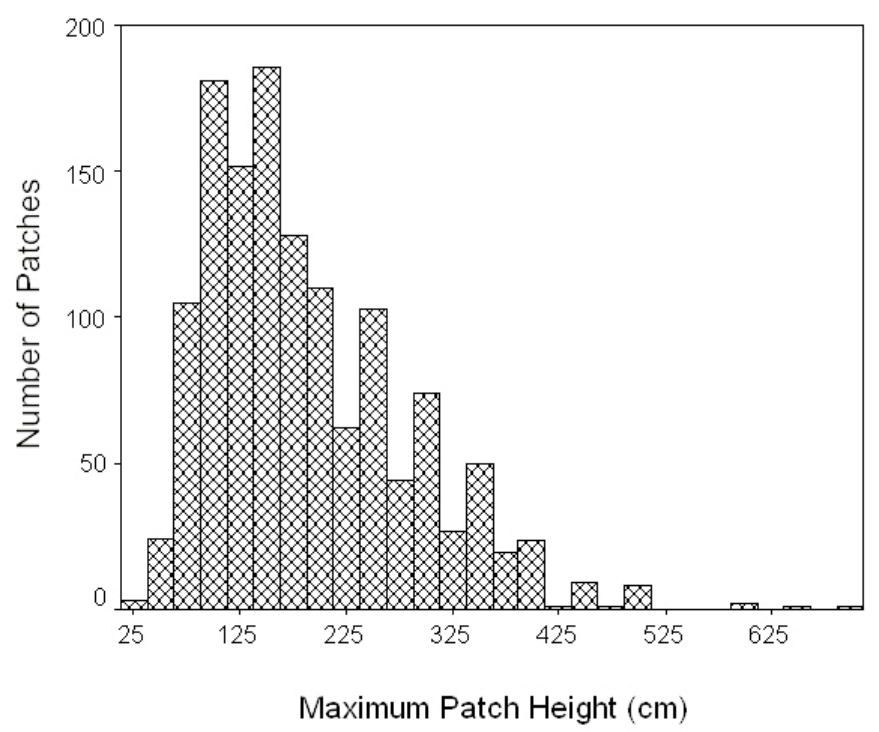

Fig. 1. Frequency distribution of maximum willow patch height (height of tallest leader; $\mathrm{cm}$ ) on the northern range of Yellowstone National Park. Data were collected during 2003-2008 (Tercek unpublished data); $n=1314$.

subplots and dominated by grasses and sedges. Subplots were chosen randomly in each site by mapping a grid over the site and using random numbers to select locations. Water sampling and temperature measurements were at fixed locations as described below, but all other measurements were duplicated at new, randomly located points within each subplot at the time of measurement.

The stratification based on 2 subplot types within each site was implemented in order to help distinguish between the effects of willow height recovery and the potential causes of this recovery. If the same patterns in bottom-up factors are seen in both herbaceous and willow-shaded subplots, then these patterns are likely not due to willow shading because the herbaceous subplots do not contain willow. Any differences between tall and short willow sites that are seen in both types of subplots are likely due to site-specific factors (such as subsurface water availability) rather than willow growth occurring since 1995.

In presenting our results, we use the following conventions: each willow site is classified as either short or tall (Table 1) and every willow site contained both willow-shaded and adjacent herbaceous subplots. Subplots are thus designated first by the site in which they are located and then by subplot type: short-willow-shaded, tall-willow-shaded, short-site-herbaceous, and tall-site-herbaceous.

\section{Statistical Analysis}

Most of the data in this study were collected as time series, so the same variable was repeatedly measured at the same location. Since measurements collected at the same location have significant autocorrelation, the traditional ANOVA assumption of independent samples is violated. To address this issue, all analyses (unless specifically noted) used a one-way repeated-measures ANOVA with between-subjects factors, which treats the repeated measurements at a single site as a within-subject effect and the different site and subplot types (tall vs. short, willow-shaded vs herbaceous) as between-subject effects (Meyers and Well 1995). Statistical tests were calculated with SPSS version 8.0. Even though willow-patch height is a continuous variable on Yellowstone's northern range (Fig. 1), we treated it as a dichotomous variable because our relatively small number of study sites did not allow us to develop linear regressions between height and our response variables.

Site Measurements

LITTER FALL AND LITTER DECOMPOSITION RATE.-In each subplot, ten $0.5-\mathrm{m}^{2}$ screens were 
fastened to the existing litter surface to collect annual litter fall. Samples were retained individually until weighing and determination of moisture content. Samples were then composited by site and ground (Wiley mill or roller table) in the lab. A subsample was retained for total carbon $(\mathrm{C})$ and nitrogen $(\mathrm{N})$ analysis.

In each subplot, 5 litter decomposition sets were installed during autumn of each year then collected the following spring. Each set contained 30 nylon mesh bags with $5 \mathrm{~g}$ of litter in each. Once removed from the field, each sample was weighed then composited by site for oven-drying and total $\mathrm{C}$ and $\mathrm{N}$ analysis.

WATER-TABLE DEPTH AND SOIL MOISTURE AT 0-10 CM DEPTH.-Four to 10 wells constructed of slotted, 3-cm-diameter PVC pipe were installed (following methods from Bilyeu et al. 2008) in each site with hand augers to a depth of 150-300 cm, approximately $30 \mathrm{~cm}$ below the water table. Following installation, wells were pumped dry several times to ensure proper flow between the well and adjacent soil. Water level below the soil surface was recorded 1-2 times per week during the growing season and monthly during the winter by using a metal rod equipped with an electrical sensor at its base.

Soil moisture $(0-10 \mathrm{~cm}$ depth) was determined gravimetrically each month from 10 randomly selected locations in each herbaceous and willow-shaded subplot. Soil moisture was calculated as a percentage of soil dry weight.

SOIL TEMPERATURE.-Soil temperature was measured every 2 hours for 2 years by data loggers (iButton Thermochron model DS1921G, Embedded Data Systems) buried $15 \mathrm{~cm}$ deep in mineral soil at 10 randomly located points within each site $(5$ points in every herbaceous or willow subplot $=10$ data loggers per site $\times$ 6 sites $=60$ data loggers).

SNOW DEPTH AND SNOW WATER EQUIVALENT.-Snow depth and snow water equivalent (SWE) were measured weekly from December to April during 2 winters by using a steel tube. Six randomly selected points within each site were chosen each week. Care was taken not to disturb the snow cover above points that contained temperature data loggers or points where $\mathrm{N}$ mineralization samples were to be collected. Samples were melted and weighed to determine snowpack density $\left(\mathrm{g} \cdot \mathrm{cm}^{-3}\right)$ and SWE.

NET NITROGEN MINERALIZATION RATE.-Nitrogen $(\mathrm{N})$ mineralization rates were estimated monthly as an index of plant nutrient availability and nutrient recycling rate. We used the closedtop core method (Adams and Attiwill 1986). The top $10 \mathrm{~cm}$ of soil was sampled at 5 randomly located points within each subplot using a 5.5-cm-diameter plastic tube, with paired tubes at each sample point. Ten grams of soil from one of the cores, which represented a nonincubated sample, was immediately mixed with $100 \mathrm{~mL}$ of $2 \mathrm{M} \mathrm{KCl}$. The other tube and soil core was capped and replaced in the ground for incubation, and displaced organic layer was replaced. After 30 days, the field-incubated sample was removed and extracted in KCL as described.

$\mathrm{NO}_{3}{ }^{-}-\mathrm{N}$ (cadmium reduction) and $\mathrm{NH}_{4}{ }^{+}-\mathrm{N}$ (indo-phenol) were determined on an autoanalyzer (Lachat Instruments, Milwaukee, WI). Net $\mathrm{NO}_{3}{ }^{-}-\mathrm{N}$ mineralization for each 30-day period was estimated by the difference between initial (unincubated sample) and final (incubated) $\mathrm{NO}_{3}{ }^{-}-\mathrm{N}$ content. Total carbon and nitrogen content for soils was determined on a LECO CHN analyzer (LECO, St. Joseph, MI). Samples were oven-dried then finely ground prior to analysis. All laboratory analyses were completed by the cooperative USGS-U.S. Forest Service Bioanalysis Laboratory on the Colorado State University campus, Ft. Collins, Colorado.

SOIL $\mathrm{CO}_{2}$ EFFLUX AS AN INDEX OF SOIL AND ROOT RESPIRATION.-We used soil $\mathrm{CO}_{2}$ efflux as an index of both plant fine-root and soil microbial respiration, following the methods of Mosier et al. (2006). Our objectives were to determine rate change as a function of soil temperature and moisture and to define relationships between soil respiration and $\mathrm{N}$ mineralization rates. First the organic litter layer was removed. Then small chambers of known volume and area were placed on the soil surface and sealed to prevent leakage. At 15-minute intervals, gas samples from the chambers were collected by syringe and evacuated tubes. No measurements were taken after a rain when soil moisture, temperature, and respiration rates rapidly change. Trace gas tubes were analyzed in cooperation with the Agricultural Research Service (ARS, Fort Collins, CO) using a fully automated Varian Model 3800 gas chromatograph. Trace-gas efflux rates were determined using the equations of Livingston and Hutchinson (1995). Gas flux was calculated as a function of concentration change within the known volume of the chamber. 


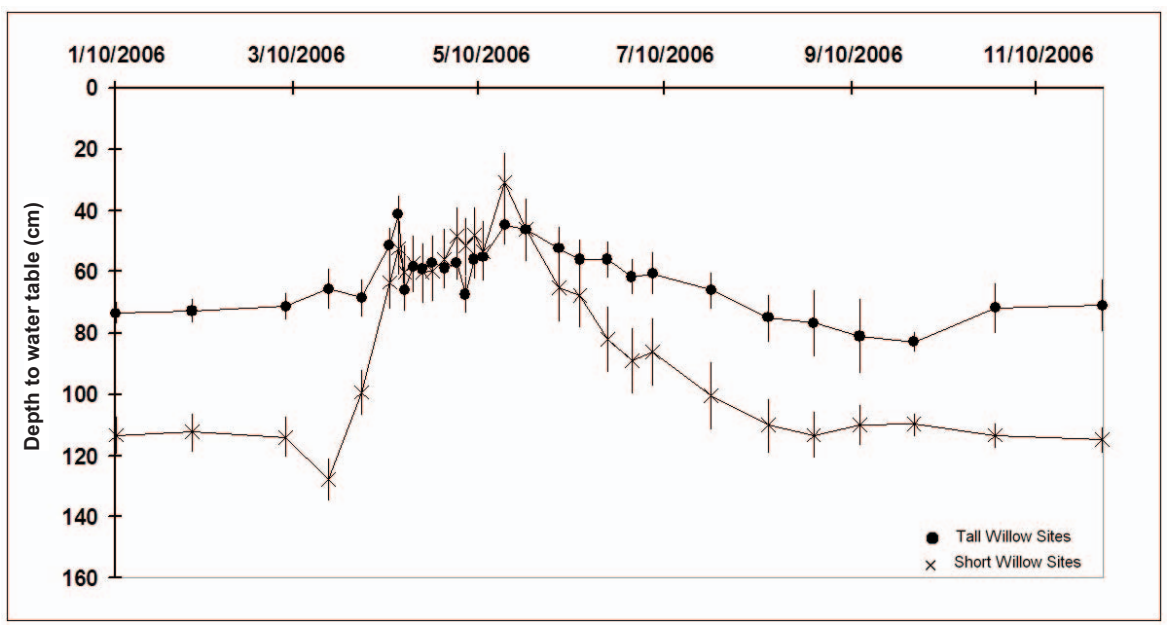

Fig. 2. Depth to water table $(\mathrm{cm})$ in 3 tall and 3 short willow sites in Yellowstone National Park. Note that values on the $y$-axis increase down the page. Bars indicate one standard error.

\section{RESULTS}

\section{Height, Productivity, and} Litter Decomposition

Our tall and short sites had significantly different means (Table 1), and the maximum heights of the tall sites are some of the tallest found on Yellowstone's northern range (Fig. 1). Note that the height differences among our sites are the result of differential height recovery since 1995. All of our sites were $<80 \mathrm{~cm}$ mean height prior to wolf reintroduction. Tall willow sites had almost double the proportion of area covered by willow and four-fold the leaf litter production as short willow sites. Leaf litter decomposition rate did not differ significantly between tall and short willow sites (Table 1).

The exclosure fences near our short willow sites on Blacktail Plateau initially might be considered "escape impediments," a factor which would reduce the propensity of elk to browse willow (Ripple and Beschta 2006). Nevertheless, we do not consider the exclosures to be a confounding influence for our analysis. If these fences were indeed acting as escape impediments, the willow in our "short" sites should be taller than willow in the surrounding areas; and they were not.

\section{Water Table Depth and Soil Moisture at 0-10 $\mathrm{cm}$ Depth}

Tall willow sites had greater soil moisture and shallower water tables than short sites. The subsurface water level in short willow sites was deeper than in tall willow sites, and equivalent depths occurred only during peak spring runoff (Fig. 2; repeated-measures ANOVA: $F_{1,23}$ $=4.96, P=0.036)$. By mid-June, water tables in short willow sites were again deeper. Surface soil moisture (0-15 cm depth) was greater (repeated-measures ANOVA: $F_{1,10}=5.4, P=$ 0.043 ) in herbaceous-tall-willow subplots than in herbaceous-short-willow subplots (Fig. 3), where the effects of willow shading were absent. Tall-willow-shaded subplots and short-willowshaded subplots had equivalent soil moisture, likely due to willow shade mitigating the topographic influences on soil temperature and moisture between sites (see below).

\section{Soil Temperature}

During the growing season (15 May-1 Sep), soils in short willow sites were warmer than soils in tall willow sites $(15 \mathrm{~cm}$ depth; Fig. 4; repeated-measures ANOVA: $F_{1,4}=32.3, P$ $=0.005)$, particularly in the herbaceous subplots. Short-site-herbaceous subplots averaged $2.4{ }^{\circ} \mathrm{C}$ warmer than tall-site-herbaceous subplots, and short-willow-shaded subplots averaged $1.3^{\circ} \mathrm{C}$ warmer than tall-willow-shaded subplots.

The winter (Dec-Mar) soil temperature pattern was reversed. During winter 2005-2006, soils in tall willow sites averaged $0.68^{\circ} \mathrm{C}$ warmer (range -0.11-1.76 ${ }^{\circ} \mathrm{C}$ warmer), and during winter 2006-2007 they averaged $0.8{ }^{\circ} \mathrm{C}$ warmer 


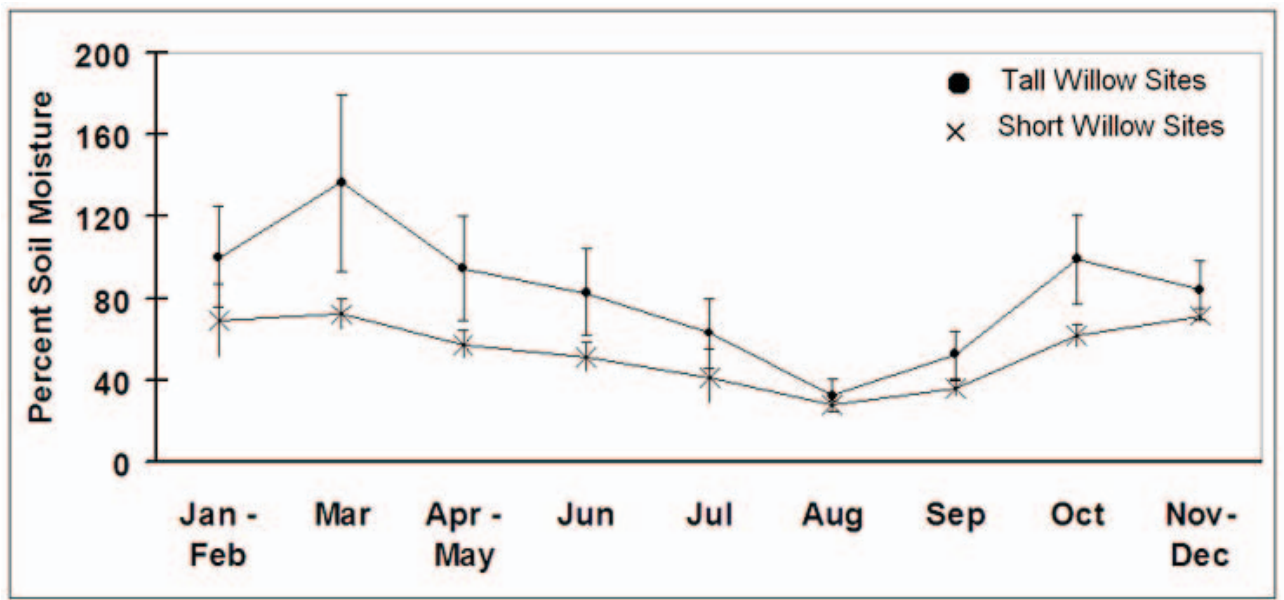

Fig. 3. Percent soil moisture (gravimetric) in herbaceous subplots adjacent to tall versus short willow patches in Yellowstone National Park. Since the patterns were the same in both years of the study, data from 2 years have been averaged and presented as one year. Bars indicate one standard error.

than soils in short willow sites. Herbaceous and willow-shaded subplots did not have significantly different winter soil temperatures.

The winter soil temperature pattern was likely due in part to the insulating effects of deeper snow in the tall willow sites.

Snow Depth and Snow Water Equivalent (SWE)

There was a positive correlation $(r=0.618$, $P<0.05)$ between the average snow depth (calculated across the entire winter) at a site and its average winter soil temperature. Tall willow sites had consistently deeper snow (measured every week for 2 winters) and greater SWE than short willow sites (Fig. 5; repeatedmeasures ANOVA: $F_{1,16}=4.6, P=0.047$ ). Over 2 winters, tall willow sites had a maximum snow depth of $50.4 \mathrm{~cm}(\mathrm{SE}=2.3)$ whereas short willow sites had $41.4 \mathrm{~cm}(\mathrm{SE}=2.8)$. Herbaceous and willow-shaded subplots within sites did not differ, indicating that willows did not cause significant snow drifting that would have contributed to greater depth in the willowshaded subplots.

\section{Soil Net Nitrogen Mineralization Rate}

Overall, tall willow sites had more than double the net $\mathrm{NO}_{3}{ }^{-}$mineralization rates of short willow sites $\left(3.5 \times 10^{-5}\right.$ vs. $1.6 \times 10^{-5} \mathrm{~g} \mathrm{~N}$. $\mathrm{g}^{-1}$ dry soil $\cdot$ day $^{-1}$; factorial ANOVA: $F_{1.547}$ $=5.9, P=0.015)$. Willow-shaded subplots had greater net $\mathrm{NO}_{3}{ }^{-}$mineralization rates than herbaceous subplots (factorial ANOVA: $F_{1,547}$ $=7.3, P=0.007)$. The difference between tall and short willow sites was due to rapid mineralization in the tall-willow-shaded subplots (Fig. 6) where rates were 2.9 times greater than in short-willow-shaded subplots. In contrast, herbaceous subplots had equivalent net $\mathrm{NO}_{3}{ }^{-}$ mineralization rates in tall and short sites (1.8 $\times 10^{-5}$ vs. $1.1 \times 10^{-5} \mathrm{~g} \mathrm{~N} \cdot \mathrm{g}^{-1}$ dry soil . day $\left.{ }^{-1}, P>0.05\right)$. The most rapid net $\mathrm{NO}_{3}{ }^{-}$ mineralization rates occurred at peak snow melt (March) in tall-willow-shaded subplots (Fig. 6). Net $\mathrm{NH}_{4}{ }^{+}$mineralization rates were not significantly different either in tall versus short willow sites or in herbaceous versus willow-shaded subplots within sites. As with net $\mathrm{NO}_{3}{ }^{-}$mineralization rates, the most rapid net $\mathrm{NH}_{4}{ }^{+}$mineralization rates were observed in tall-willow-shaded subplots at peak snowmelt.

\section{Soil $\mathrm{CO}_{2}$ Efflux as an Index of Soil Respiration Rate}

Soil $\mathrm{CO}_{2}$ efflux varied primarily as a function of temperature. $\mathrm{CO}_{2}$ efflux had a strong correlation to soil temperature at the time of sample collection (Pearson's $r=0.8, P<0.05$ ). As described above, soils in short willow sites were significantly warmer than soils in tall willow sites, and herbaceous subplots were warmer than shaded subplots in every season except winter. Consequently, $\mathrm{CO}_{2}$ efflux was 2.4 times greater in short than tall willow sites, and the difference was maintained in both herbaceous 

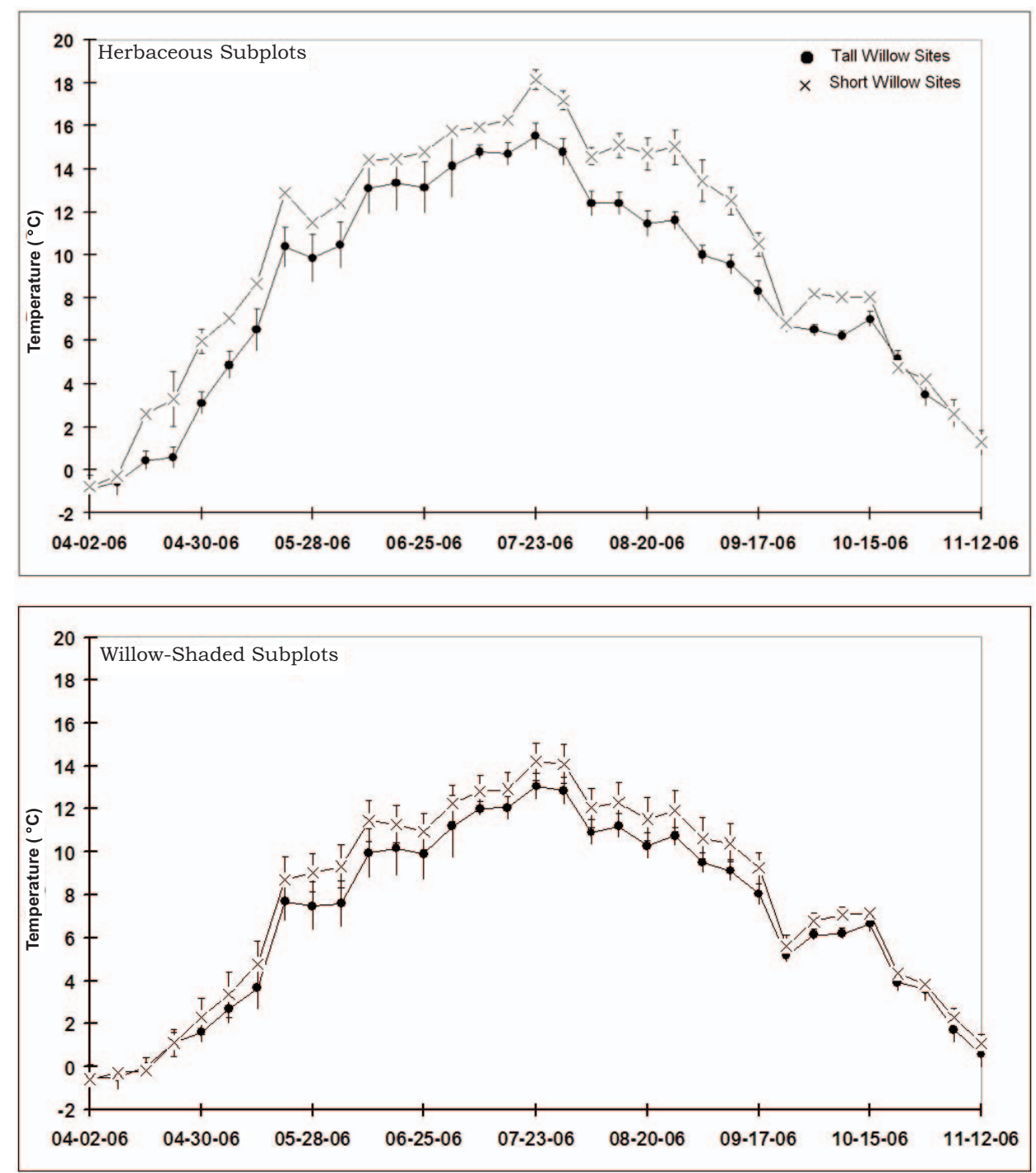

Fig. 4. Weekly average soil temperatures at $15-\mathrm{cm}$ depth in tall versus short willow patches in Yellowstone National Park. Temperatures were measured every 2 hours (25-70 data loggers used depending on season) in herbaceous subplots adjacent to the willow thickets and in willow-shaded subplots. Since data from both years of our study show the same pattern, only one growing season is presented. Bars indicate one standard error.

and willow-shaded subplots. A multiple linear regression of temperature and moisture against $\mathrm{CO}_{2}$ flux explained only $0.4 \%$ more of the variance than a simple linear regression that used temperature as the only predictor variable $\left(\mathrm{R}^{2}\right.$ $=0.645$ vs. $\left.\mathrm{R}^{2}=0.641\right)$.

\section{Discussion}

Willow height recovery since 1995 has not been uniform on Yellowstone's northern range.
Willow patches in some areas have exceeded $250 \mathrm{~cm}$ maximum height, allowing them to escape elk browsing (Keigley and Frisina 1998), while others, often nearby or adjacent, still have an average height of $<80 \mathrm{~cm}$ (Tercek unpublished data). The behaviorally mediated trophiccascade hypothesis explains this differential recovery of riparian woody plants (willow, aspens, and cottonwoods) as the result of the topdown effects of wolf predation on elk browsing; and it explicitly dismisses the importance of 

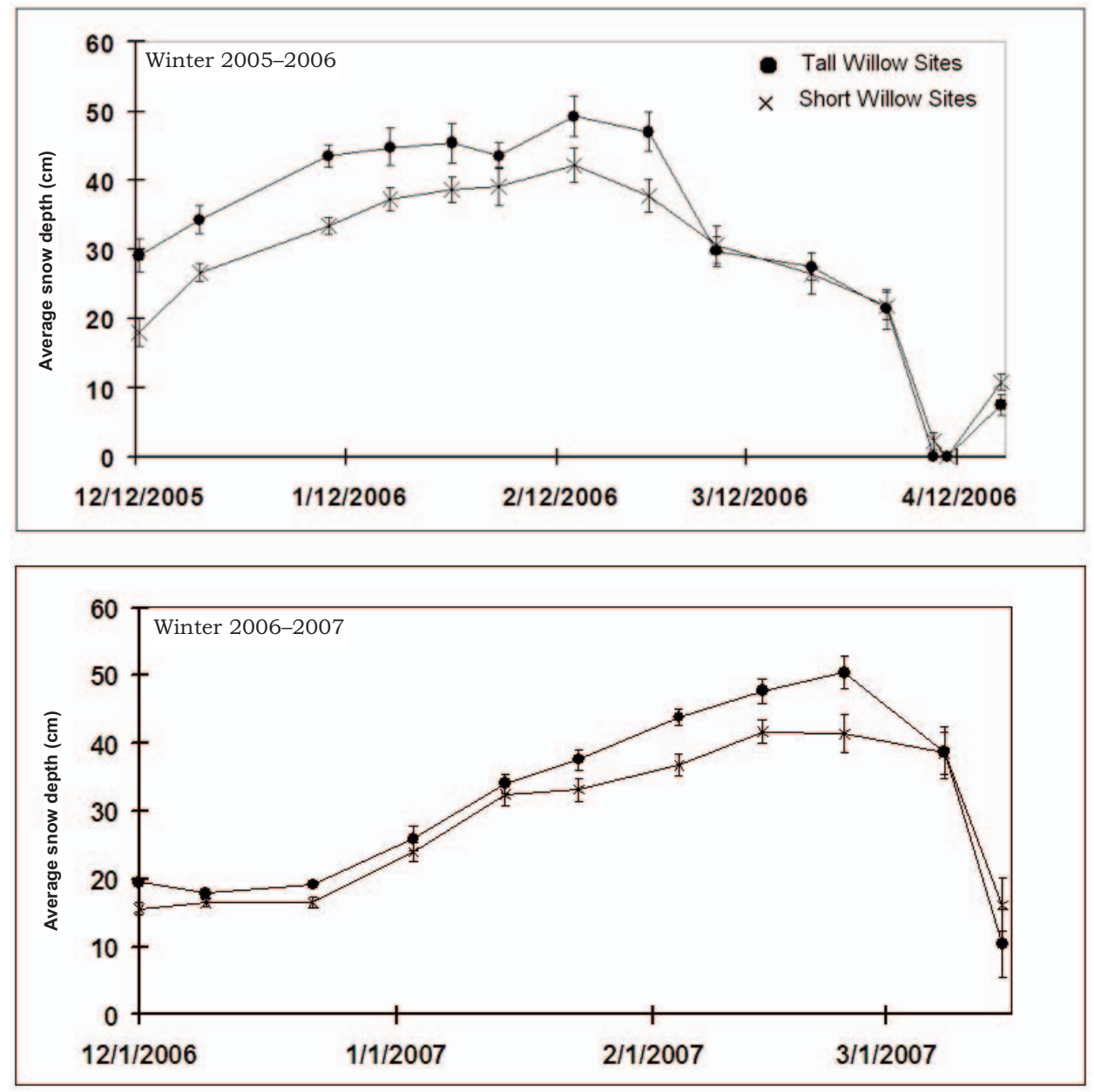

Fig. 5. Average snow depth $(\mathrm{cm})$ during 2 winters (winter 2005-2006 and winter 2006-2007) in tall willow versus short willow sites in Yellowstone National Park. Bars indicate one standard error.

abiotic factors such as water availability (Ripple and Beschta 2003, 2004a, 2004b, 2005, 2006, 2007). This hypothesis was based primarily on observations of site-specific characteristics, such as proximity to wolf territory, escape impediments for elk, and obstacles that would prevent elk from seeing wolves. In contrast, studies that focused on elk and wolf movements over fine temporal and spatial scales have challenged the predictions of the behaviorally mediated topdown theory (Creel and Winnie 2005, Creel et al. 2005, Christianson and Creel 2008, Creel and Christianson 2009). Most significantly, elk consumed more willow when wolves were present in an area than when wolves were absent; and increased snow depth, which limits elk access to preferred herbaceous forage, had a much stronger effect on the amount of willow consumed by elk than the presence of wolves (Creel and Christianson 2009). These findings suggest that wolves do affect elk browsing of willow, but the effects are opposite those predicted by the behaviorally mediated trophiccascade theory and not as strong.

Plant-based studies have presented an alternative to research that focuses on elk or wolf behavior. Using fenced exclosures and artificial dams, Johnston et al. (2007) and Bilyeu et al. (2008) concluded that abiotic bottom-up factors that have potential to limit plant productivity interact with top-down mechanisms in Yellowstone (Johnston et al. 2007, Bilyeu et al. 2008).

Rather than using fences and artificial dams to manipulate willow height, the present study 


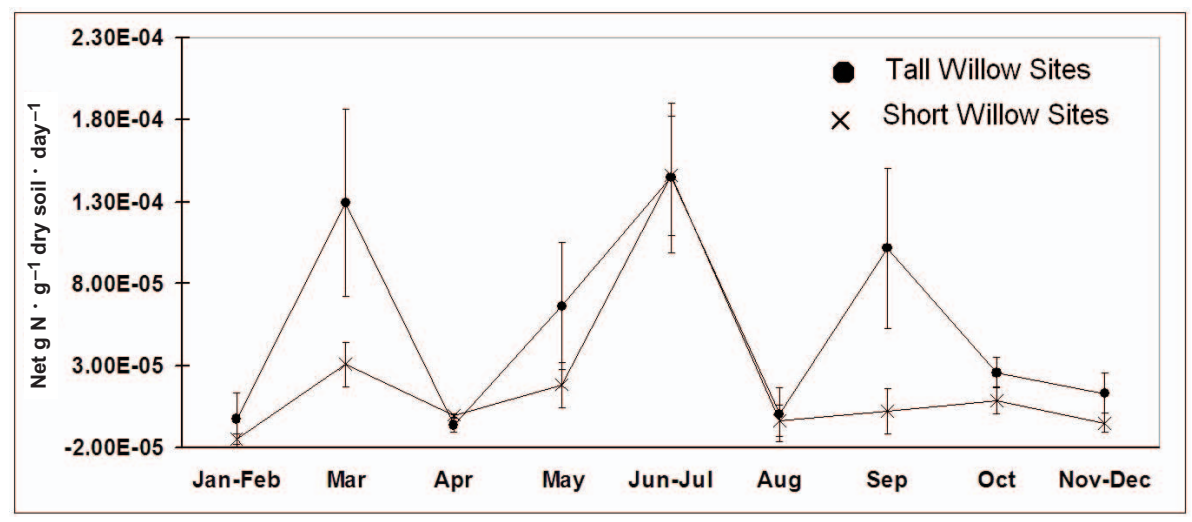

Fig. 6. $\mathrm{Net}^{\mathrm{NO}_{3}-}$ mineralization rate $\left(\mathrm{g} \mathrm{N} \cdot \mathrm{g}^{-1}\right.$ dry soil $\cdot$ day $\left.{ }^{-1}\right)$ in and near willow patches in Yellowstone National Park. Data for 2 years have been averaged and presented as a single time series. Bars indicate one standard error.

examined abiotic factors in naturally occurring (nonexperimental) tall $(>250 \mathrm{~cm}$ max. height) and short $(<250 \mathrm{~cm}$ max. height) willow sites. All of our sites were $<80 \mathrm{~cm}$ mean height prior to 1995 (Singer et al. 1994, Singer unpublished data) and have experienced variable recovery since. Our results are consistent with Johnston et al. (2007) and Bilyeu et al. (2008), supporting the view that bottom-up factors interact with top-down effects to control the pace of willow recovery.

Tall willow sites (>250 cm height; Table 1) in our study had shallower water tables, moister soil (0-10 cm depth), more rapid net nitrogen (N) mineralization in the spring, greater snow depth and snow water equivalent, cooler summer soil temperatures, lower spring root/soil respiration rates, and warmer winter soil temperatures than nearby short willow $(<250 \mathrm{~cm})$ sites. Most of these differences were seen in both herbaceous areas adjacent to the willow patches and in the willow patches themselves, suggesting that they were due to site differences, such as microtopography, aspect, or elevation, rather than effects of taller willow, such as increased shading. In contrast, net $\mathrm{N}$ mineralization rates, which were greater in tall-willowshaded than in short-willow-shaded subplots may have been the result of increased willow growth in tall sites. Increased shading in tall willow sites may have provided more favorable temperature and moisture conditions for $\mathrm{N}$ mineralization (Figs. 4, 7).

Our results are not consistent with those obtained by previous researchers who have used the same study sites in Yellowstone. In contrast to authors who emphasize that elk perceive lower predation risk in upland habitats, we suggest that willows in upland habitats are shorter because they are often farther from the water table. Our results suggest that reduced water availability contributes to reduced primary productivity (Fig. 2, Table 1). It therefore is likely that both top-down (e.g., predation risk) and bottom-up factors (e.g., water availability) explain the willow height differences observed by Ripple and Beschta (2006) in upland versus lowlying riparian areas.

Some of the studies emphasizing a top-down explanation for the reported willow recovery in Yellowstone are based on measurements that did not have the power to detect the influence of abiotic factors on plant productivity. We suggest that measurements used in the present study are more reliable. For example, our data show that nearby willow patches have significantly different water availability and that these differences correlate with willow height (Figs. $2,3)$. In contrast, Beyer at al. (2007) concluded that water-table depth and precipitation did not have a significant relationship with the growth intervals they measured in willow stem cross sections. But the Beyer et al. (2007) estimates of water-table depth are based on theoretical calculations from proxy variables, such as watershed area and stream velocity, rather than actual field data. Similarly, Ripple and Beschta (2006) concluded that water-table depth did not explain the height of willow thickets, but they did not directly measure this variable with subsurface wells, as in the present study. They instead assumed that water-table depth is correlated with 


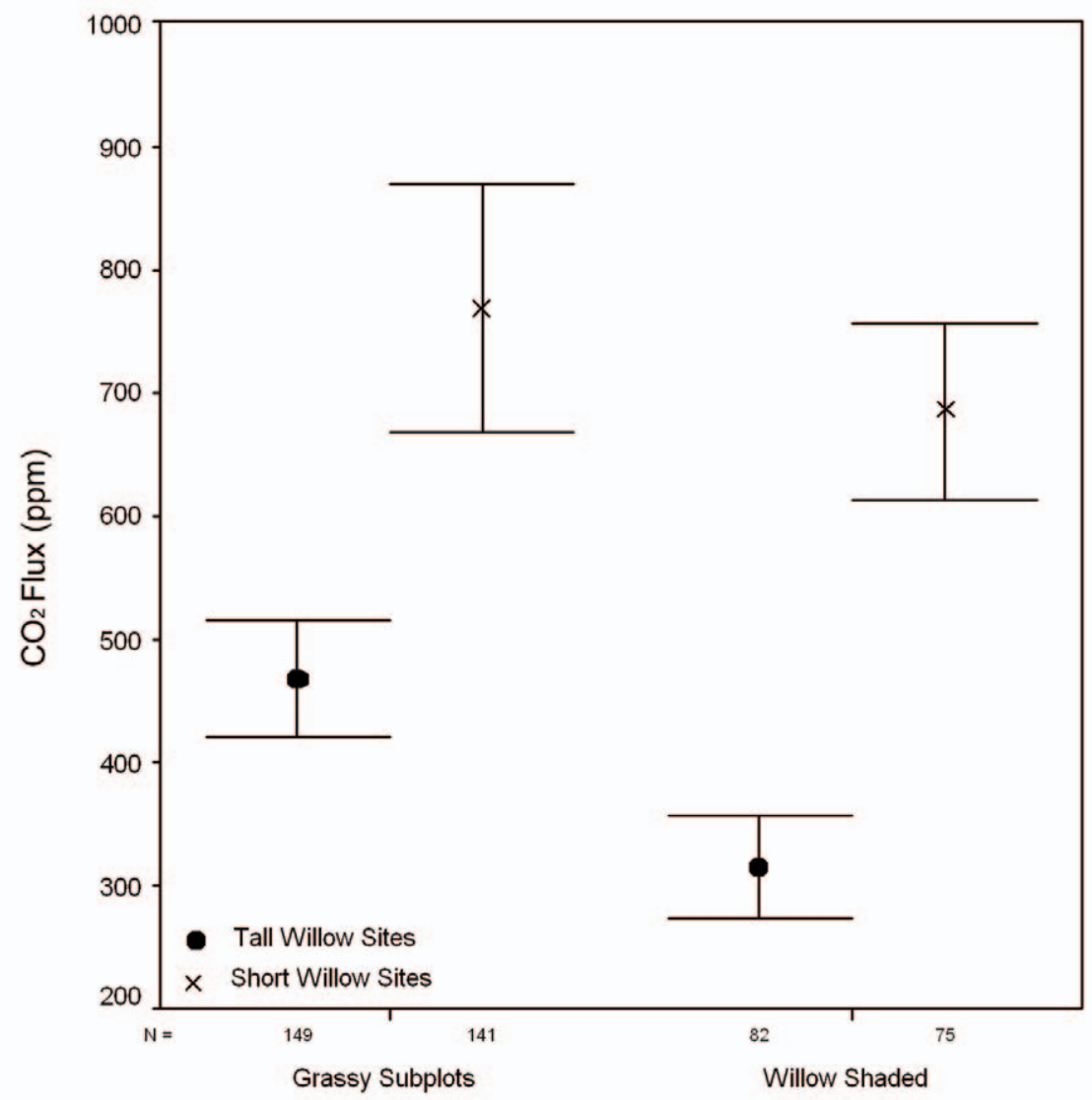

Fig. 7. Soil $\mathrm{CO}_{2}$ flux (parts per million) in tall versus short willow sites in Yellowstone National Park. Measurements were taken weekly during spring 2006 and spring 2007. Bars indicate one standard error.

the distance between the willow root crown and the surface of nearby streams.

Our field observations indicate that watertable depth is not correlated with the distance between the soil surface and the nearby stream surface. While digging our sample wells, it became clear that subsurface soil texture, rock content, and the influence of old stream courses created subterranean channels that allowed the water table to fluctuate greatly on a fine spatial scale. Direct measurements of water-table depth with wells in each area of interest are the only practical way at present to accurately determine whether this variable has a relationship with willow height. It is also important to measure water-table depth during the entire growing season because tall and short willow sites may have similar depths during some parts of the year, but short sites may experience a much shorter period of water abundance (Fig. 2).
Most of the differences observed between tall and short willow sites in this study, such as increased water and nitrogen availability, could have directly beneficial effects on plant productivity, while the effects of other factors are less clear. These abiotic factors deserve further investigation at a larger number of sites in order to confirm their ability to increase primary productivity. The greater snow depth in tall willow sites $(\sim 10 \mathrm{~cm}$ maximum difference) was probably not sufficient to discourage elk browsing, but increased insulation from deeper snow did raise winter soil temperatures slightly. Snow depth and winter soil temperatures were positively correlated $(r=0.618, P<0.05)$, and taller sites had significantly deeper snow (Fig. 5). Greater snow depth might account for some of the increased $\mathrm{N}$ mineralization observed in these sites, particularly during the March snowmelt (Fig. 6). Soils in our tall willow sites were 
warm enough to undergo freeze-thaw cycles during the winter (data not shown), which has been shown to stimulate the growth of a unique microbial community that increases $\mathrm{N}$ mineralization rates (Monson et al. 2006).

The importance of reduced root/soil respiration in tall willow sites deserves further study. Tall willow sites, which were more productive (Table 1), had lower soil respiration rates in both their willow-shaded and herbaceous subplots, primarily because they had lower soil temperatures (Fig. 4); but tall willow sites also had more rapid net $\mathrm{N}$ mineralization rates, which are largely controlled by the soil microbial community.

There are some caveats associated with the present study. We made intensive, repetitive measurements, but they were taken from a small number of study sites. This small number was primarily due to the limited resources for the study and our desire to take advantage of data collected from sites used by previous researchers (Ripple and Beschta 2006, Johnston et al. 2007, Bilyeu et al. 2008). The number of study sites used in this study is similar to the number used by Johnston et al. (2007) and Bilyeu et al. (2008). Nevertheless, this study should be regarded as preliminary until the patterns observed have been replicated across the entire northern range.

Our study did not measure elk browsing levels, so it is impossible for us to make general statements about the relative importance of top-down versus bottom-up factors. Nevertheless, browsing levels measured in willow stands directly adjacent to our Blacktail Creek sites during our study period (Bilyeu et al. 2008) were not significantly different from those measured in the same location prior to wolf reintroduction (Singer et al. 1994). This suggests that factors other than wolf-mediated reductions in elk browsing are responsible for willow height recovery in these areas. We suggest that the abiotic, resource-limiting, or bottom-up factors identified by this study deserve further investigation. These factors may influence the pace of willow recovery as much as top-down mechanisms.

\section{ACKNOWLEDGMents}

This work was funded by a grant from the Natural Resources Protection Program (NRPP). We thank Linda Zeigenfuss (USGS) and Lorna
McIntyre for help with field work. We also thank Christie Hendrix and Christine Smith (National Park Service) for their help with research permits and logistics. Funding for this study was originally obtained by Dr. Francis Singer (deceased), who spent many years as a wildlife ecologist in Yellowstone National Park. We thank David J. Cooper, Duncan Patten, Linda C. Zeigenfuss, Martha Apple, and 2 anonymous reviewers for helpful comments on drafts of the manuscript.

\section{Literature Cited}

Adams, M.A., AND P.M. ATTIWILL. 1986. Nutrient cycling and nitrogen mineralization in eucalypt forests of southeastern Australia. II. Indices of nitrogen mineralization. Plant and Soil 92:341-362.

Beschta, R.L. 2003. Cottonwoods, elk, and wolves in the Lamar Valley of Yellowstone National Park. Ecological Applications 13:1295-1309.

2005. Reduced cottonwood recruitment following extirpation of wolves in Yellowstone's northern range. Ecology 86:391-403.

Beyer, H.L., E.H. Merrill, N. Varley, and M.S. Boyce. 2007. Willow on Yellowstone's northern range: evidence for a trophic cascade? Ecological Applications 17:1563-1571.

Bilyeu, D.M., D.J. CoOper, AND N.T. HobBs. 2008. Water tables constrain height recovery of willow on Yellowstone's northern range. Ecological Applications 18: 80-92.

Chadde, S., and C. Kay. 1991. Tall-willow communities on Yellowstone's northern range: a test of the "natural regulation" paradigm. Pages 231-262 in R.B. Keiter and M.S. Boyce, editors, The Greater Yellowstone Ecosystem: redefining America's wilderness heritage. Yale University Press, New Haven, CT.

Christianson, D., AND S. CREEL. 2008. Risk effects in elk: sex-specific responses in grazing and browsing due to predation risk from wolves. Behavioral Ecology 19:1258-1266.

Creel, S., AND J. Winnie. 2005. Responses of elk herd size to fine-scale spatial and temporal variation in the risk of predation by wolves. Animal Behavior 69:11811189.

Creel, S., and D. Christianson. 2009. Wolf presence and increased willow consumption by Yellowstone elk: implications for trophic cascades. Ecology 90:24542466.

Creel, S., J. Winnie, B. Maxwell, K. Hamlin, and M. CreEL. 2005. Elk alter habitat selection as an antipredator response to wolves. Ecology 86:3387-3397.

Despain, D.G. 1990. Yellowstone vegetation, consequences of environment and natural history in a natural setting. Roberts Rinehart Publishers, Boulder, CO.

Eberhardt, L.L., P.J. White, R.A. Garrott, and D.B. Houston. 2007. A seventy-year history of trends in Yellowstone's northern elk herd. Journal of Wildlife Management 71:594-602.

Fortin, D., H.L. Beyer, M.S. Boyce, D.W. Smith, T. Duchesne, and J.S. MaO. 2005. Wolves influence elk movements: behavior shapes a trophic cascade in Yellowstone National Park. Ecology 86:1320-1330. 
Johnston, D.B., D.J. Cooper, and N.T. Hobbs. 2007. Elk browsing increases above-ground growth of waterstressed willows by modifying plant architecture. Oecologia 154:467-478.

Kauffman, M., N. Varley, D. Smith, D. Stahler, D. MacNULTY, AND M. BoYCE. 2007. Landscape heterogeneity shapes predation in a newly restored predator-prey system. Ecology Letters 10:690-700.

Keigley, R.B., AND M.R. Frisina. 1998. Browse evaluation by analysis of growth form. Volume 1, Methods for evaluating condition and trend. Montana Fish, Wildlife and Parks, Bozeman, MT.

LARSEN, E.J., AND W.J. RiPPLE. 2003. Aspen age structure in the northern Yellowstone Ecosystem, USA. Forest Ecology and Management 179:469-482.

Lemke, T.O., J.A. Mack, and D.B. Houston. 1998. Winter range expansion by the northern Yellowstone elk herd. Intermountain Journal of Sciences 4:1-9.

Livingston, G.P., AND G.L. Hutchinson. 1995. Enclosure-based measurement of trace gas exchange: applications and sources of error. Pages 14-51 in P.A. Matson and R.C. Hariss, editors, Biogenic trace gases: measuring emissions from soil and waters. Blackwell Scientific, London.

Meyers, J.L., AND A.D. WeLL. 1995. Research design and statistical analysis. Lawrence Erlbaum Associates, Publishers, Hillsdale, NJ.

Monson, R.K., D.L. Lipson, S.P. Burns, A.A. TurnipSeed, A.C. Delany, M.W. Williams, and S.K. SCHMidT. 2006. Winter forest soil respiration controlled by climate and microbial community composition. Nature 439:711-714.

Mosier, A.R., A.D. Halvorson, C.R. Reule, and X.J. Liu. 2006. Net global warming potential and greenhouse gas intensity in irrigated cropping systems in Northeastern Colorado. Journal of Environmental Quality 35:1584-1598.
National Research Council. 2002. Ecological dynamics on Yellowstone's Northern Range. National Academy Press, Washington, DC.

Ripple, W., E. Larsen, R. Renkin, and D.W. Smith. 2001. Trophic cascades among wolves, elk, and aspen on Yellowstone National Park's northern range. Biological Conservation 102:227-234.

RIPPLE, W.J., AND R.L. BESCHTA. 2003. Wolf reintroduction, predation risk, and cottonwood recovery in Yellowstone National Park. Forest Ecology and Management 184:299-313.

2004a. Wolves and the ecology of fear: can predation risk structure ecosystems? Bioscience 54:755-766. . 2004b. Wolves, elk, willows, and trophic cascades in the upper Gallatin Range of southwestern Montana, USA. Forest Ecology and Management 200:161-181. 2005. Willow thickets protect young aspen from elk browsing after wolf reintroduction. Western North American Naturalist 65:118-122.

2006. Linking wolves to willows via risk-sensitive foraging by ungulates in the northern Yellowstone Ecosystem. Forest and Ecology Management 230: 96-106.

2007. Restoring Yellowstone's aspen with wolves. Biological Conservation 138:514-519.

Singer, FJ., L.C. Mark, and R.C. Cates. 1994. Ungulate herbivory of willows on Yellowstone's northern winter range. Journal of Range Management 47:435443.

WAGNER, FH. 2006. Yellowstone's destabilized ecosystem: elk effects, science, and policy conflict. Oxford University Press, New York, NY.

Received 16 June 2009 Accepted 12 February 2010 